\section{Use of quantitative colorimetry and visual evaluation for color characterization of triticale seeds after phenol reaction}

\author{
Juliana Sawada Buratto ${ }^{1 *}$ (iD, Carlos Henrique dos Santos Fernandes², Jean Carlos \\ Gomes Rosa ${ }^{1}$, Aline Taiane de Freitas Vanzo ${ }^{1}$ (D) João Henrique Caviglione ${ }^{1}{ }^{(\mathbb{D}}$
}

ABSTRACT: Quantitative colorimetry can be used to characterize the color of triticale seeds submitted to the phenol test. This study aimed to characterize the color of triticale seeds after the phenol test by visual color evaluation and quantitative colorimetry using the CIELAB color space. The evaluated seeds came from 88 triticale genotypes from the IDR-Paraná Germplasm Bank. The colorimetric data for $L$ (lightness) and chromaticity coordinates a* and $\mathrm{b}^{*}$ of the seeds before and after phenol reaction were obtained using a Minolta CR400 colorimeter. The score scale ranged from 1 (very weak or absent color) to 9 (very dark color) and evaluated visually the seed color after phenol reaction. Seeds classified as score 1 showed mean values of $46.3,6.6$, and 16.4 for $L$, $a^{*}$, and $b^{*}$, respectively. On the other hand, seeds classified as dark or very dark showed values equal to or lower than 28.4 for L, 5.6 for chromaticity $a^{*}$, and 6.0 for chromaticity $b^{*}$. The use of colorimetric parameters showed a practical application and low subjectivity in the classification of the color of triticale seeds after phenol reaction.

Index terms: $\mathrm{x}$ Triticosecale Wittmack, color space, phenotyping, genetic diversity.

Uso de colorimetria quantitativa e avaliação visual para caracterização de cor de sementes de triticale após reação ao fenol

RESUMO: O uso de colorimetria quantitativa pode ser empregada para caracterização de cores em sementes de triticale submetidas ao teste de fenol. Este trabalho teve como objetivo efetuar a caracterização da coloração de sementes de triticale após o teste de fenol utilizando a avaliação visual de cores e colorimetria quantitativa utilizando o sistema CIELAB. As sementes avaliadas foram provenientes de 88 genótipos de triticale do banco de germoplasma do IDR-Paraná. Os dados colorimétricos para L (luminosidade), cromaticidade $a^{*}$ e b* das sementes antes e após a reação ao fenol foram obtidos usando um colorímetro Minolta modelo CR-400. A escala de notas utilizada variou de 1 (coloração muito fraca ou ausente) até 9 (coloração muito escura) para avaliação visual de cor nas sementes após a reação ao fenol. As sementes classificadas como nota 1 apresentaram valores médios de 46,3; 6,6 e 16,4 para L, a* e b*, respectivamente. Em outro extremo, tem-se as sementes classificadas como "escuras" ou "muito escuras", e verificou-se valores iguais ou inferiores de 28,4 para L, 5,6 para cromaticidade a* e 6,0 para cromaticidade b* 0 uso dos parâmetros colorimétricos revela-se de aplicação prática, com menor subjetividade na classificação da coloração das sementes de triticale após a reação ao fenol.

Termos para indexação: x Triticosecale Wittmack, espaço de cor, fenotipagem, diversidade genética.
Journal of Seed Science, v.43, e202143008, 2021

http://dx.doi.org/10.1590/ 2317-1545v43232700

\footnotetext{
*Corresponding author E-mail: jsburatto@iapar.br
}

Received: $1 / 2 / 2020$. Accepted: $11 / 13 / 2020$.

\footnotetext{
${ }^{1}$ Instituto de Desenvolvimento Rural do Paraná - IAPAR - EMATER, 86047-902 - Londrina, PR, Brasil.

${ }^{2}$ Universidade Estadual de Londrina (UEL), Departamento de Agronomia, Caixa Postal 10.011, 86057-970 Londrina, PR, Brasil.
} 


\section{INTRODUCTION}

The process of morphological characterization of triticale seeds is laborious since a large number of common traits in seeds make it difficult to differentiate between genotypes. The chemical phenol test has been used in the literature to characterize and assist in the discrimination of several species of cereals such as wheat (Menezes and Bellé, 1995), rice (Sing et al., 2017), barley and rye (Moya et al., 2006). One of the characteristics required when the request for protection of a triticale cultivar is made at the National Plant Varieties Protection Service of the Ministry of Agriculture, Livestock and Food Supply (SNPC-MAPA) is the response to the phenol reaction in seeds (Brasil, 2002).

The color due to the phenol reaction was first reported by Pieper in 1922, as the seeds treated with a phenol derivative were dyed with different tones of brown when dried (Menezes and Bellé, 1995). The phenol test has the advantage of speed, easy of characterization, and constant reaction for each cultivar. Information or data regarding the morphological characterization of triticale genotypes are scarce in the literature, especially data dealing with genetic variability for the trait color of seeds submitted to phenol reaction.

The evaluation of different tones of colors observed in the plant or its parts is commonly used to carry out the morphological characterization. Although the visual evaluation of color in plants is a common practice, the results are subject to the evaluator effect since the results obtained by people with little experience may have low repeatability and/or reproducibility. Color is a trait that is difficult to assess, as it is affected by the perception of each individual, and also has a subjective nature. In this context, quantitative colorimetry has been used to characterize the color of several plant species successfully (Jackson et al., 2018; 2019; Kläsener et al., 2020; Gentallan et al., 2019; Bonfatti-Júnior and Lengowski, 2018). One of the most used colorimetric methods is the CIE LAB system, which was described in 1976 and considers three spatial axes $\left(L, a^{*}\right.$, and $\left.b^{*}\right)$ perpendicular to each other, whose points provide more uniform numerical differences relative to visual differences (Commission Internationale de l'Eclairage, 2004).

The process of morphological characterization for colors can be carried out with greater objectivity, and this study shows that colorimetric data can be used for this purpose. In this sense, this study aimed to characterize the color of triticale seeds after the phenol test using both the visual evaluation and the quantitative colorimetry, which uses the CIELAB color space.

\section{MATERIAL AND METHODS}

The seeds evaluated in this study came from 88 triticale genotypes of the Germplasm Bank of the Winter Cereals Program of the Instituto de Desenvolvimento Rural do Paraná - IAPAR - EMATER (IDR Paraná). Among the genotypes are recommended cultivars, lines, and introductions from other research institutions. The seeds of the 88 triticale genotypes were obtained in the $\mathbf{2 0 1 8}$ growing season, during the cultivation carried out in Londrina, PR, Brazil. Cultural practices followed the technical recommendations for the crop in the State of Paraná. The plots were harvested after physiological maturation, and the seeds were maintained in a cold chamber until laboratory evaluations were carried out.

In the first stage, a 50-gram seed sample was randomly sampled for each triticale genotype, in which the color parameters $\mathrm{L}, \mathrm{a}^{*}$, and $\mathrm{b}^{*}$ were evaluated in duplicate. In the second stage, a visual color evaluation was carried out in the seeds subjected to the reaction with phenol solution, and the color parameters $L$, $a^{*}$, and $b^{*}$ were also obtained. The objective measurements of seed colors ( $L, a^{*}$, and $b^{*}$ ) were obtained by a Minolta $C R-400$ colorimeter. The equipment was calibrated using a white reference block provided by the manufacturer. The CIE 1976 color space was used and the color parameters $L, a^{*}$, and $b^{*}$ were evaluated. The $L$ value indicates lightness, varying from black $(L=0)$ to white $(L=$ $100)$, the $a^{*}$ value characterizes the color of the region from green $\left(-a^{*}\right)$ to red $\left(+a^{*}\right)$, and the $b^{*}$ value indicates the color in the range from blue $\left(-b^{*}\right)$ to yellow $\left(+b^{*}\right)$.

The visual evaluation of colors was carried out according to the methodology described by the National Plant Varieties Protection Service of the Ministry of Agriculture, Livestock and Food Supply (Brasil, 2002). The seeds were 


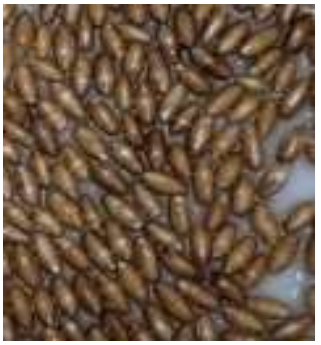

Score 1

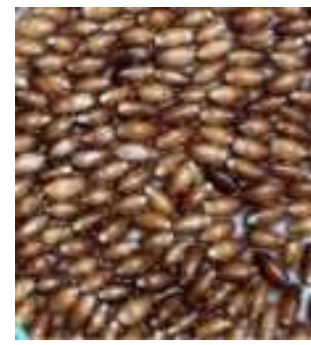

Score 3

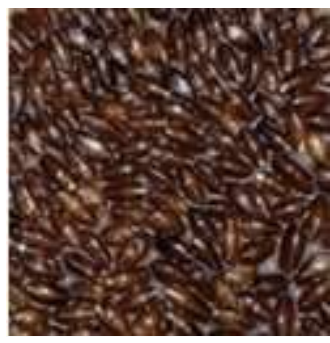

Score 5

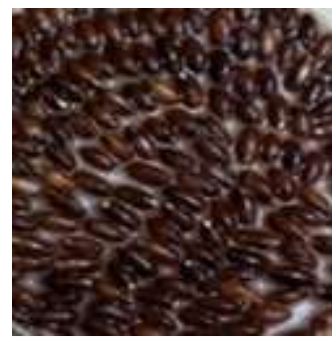

Score 7

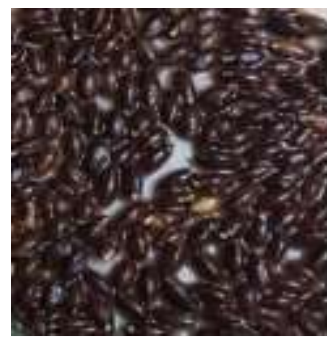

Score 9

Figure 1. Color intensity in triticale seeds after phenol reaction was evaluated using a visual score scale ranging from 1 (absent or very weak color) to 9 (very dark color).

soaked in distilled water for 16 to 20 hours. After this period, the water was drained and the seeds with the crease positioned downwards were placed in Petri dishes containing a sheet of filter paper, and a $1 \%$ phenol solution was added so that $3 / 4$ of the grains were submerged. The Petri dishes were closed and taken to a germinator for 4 hours at a temperature of 19 $\pm 1{ }^{\circ} \mathrm{C}$. Subsequently, the seeds were quickly evaluated without prior washing for the color presented in the pericarp. The visual evaluation used a scale of grades that varied from 1 to 9 , in which: 1) the seeds with no reaction or very weak brown color caused by the phenol solution; 3) the seeds expressed a light brown color; 5) the seeds were classified as "medium" color; 7) "dark brown" coloration was observed in the seeds; 9) it represents the very intense reaction to phenol, in which the color of the karyopsis was shown as "very dark brown" (Figure 1). After this visual evaluation, the samples were taken to a fume hood and the phenol solution was drained and the seeds were dried for approximately 20 minutes on a paper towel. After this period, the color parameters $\mathrm{L}, \mathrm{a}$ * and $\mathrm{b}$ * were again obtained in duplicate with the Minolta colorimeter.

Pearson's correlation test was applied to obtain the magnitude and sense of associations between the studied variables. The significance of the correlation coefficient estimates was assessed at 5,1 , and $0.1 \%$ probability using the t-test with n-2 degrees of freedom. An analysis of variance was carried out considering the completely randomized design. The means were compared using the LSD (least significant difference) test at the $5 \%$ probability level using the statistical software Sisvar ${ }^{\circledR}$ (Ferreira, 2014).

\section{RESULTS AND DISCUSSION}

Table 1 shows the results of descriptive statistics for visual color score and colorimetric parameters ( $L$, $a^{*}$, and $b^{*}$ ) evaluated in triticale seeds before and after reaction with phenol solution. The color of triticale grains is a phenotypic criterion used to characterize or select genotypes in breeding programs. The visual evaluation of colors after phenol reaction showed that the scores ranged from 1 (absence/very light) to 9 (very dark), and the overall mean score was 5.82. Chromaticity a* ranged from 5.52 to 7.49 , with a mean value of 6.35 before phenol reaction. The a* value varied from 4.30 to 7.56 after phenol reaction and presented a mean value of 5.87. Positive $a^{*}$ values tend towards red and negative values tend towards green. Moreover, positive $b^{*}$ values indicate a trend towards yellow and negative towards blue. The samples had a higher mean $b^{*}$ value (16.07) before phenol reaction. The evaluation of colorimetric parameters showed a higher variance and standard deviation for $\mathrm{L}, \mathrm{a}^{*}$, and $\mathrm{b}^{*}$ after phenol reaction (Table 1 ).

Figure 2 shows that the $\mathrm{Y}$-axis corresponds to $\mathrm{L}$, which refers to the lightness of the sample, with values close to 100 representing white and values close to 0 representing black. The darkening observed in the seed pericarp can be quantified by $L$, which showed a mean value before phenol reaction of 42.78 and a reduction to 30.86 after treatment with phenol (Table 1). In general, triticale seeds after phenol reaction had a darker color with different tones of brown, which can vary from ivory to very dark brown. The phenol reaction in seeds is based on the activity of polyphenol oxidases, and the reaction is controlled primarily by the enzyme tyrosinase (Joshi and Banerjee, 1969 apud Menezes and Bellé, 1995). The color change is due to the formation of dark insoluble pigments (melanin), and the 
characterization of genotypes can be performed according to the intensity of melanin production, in which the seed would present different tones of brown (Moya et al., 2006). The color formation in the aleurone layer occurs due to the phenol oxidation in two reactions. In the first reaction, the phenol aromatic ring can be hydroxylated to form catechols or quinols, respectively. In the second reaction, quinols or catechols undergo oxidation to form quinones (Sing et al., 2017).

Figure 3 shows Pearson's correlation coefficient estimates. The correlation estimates ranged from $-0.89 * * *$ (visual score $\mathrm{x} \mathrm{b}^{*}$ after phenol) to $0.96^{* * *}$ (visual score $\mathrm{x} \mathrm{L}$ after phenol). The visual score showed a negative correlation with high magnitude and high significance $(P<0.001)$ with $L, a^{*}$, and $b^{*}$ obtained from seeds submitted to phenol. This result indicates that the higher the visual score, the lower the $L, a^{*}$, and $b^{*}$ values in seeds after treatment with phenol. Another question that was raised was whether seeds with a lighter color would show less response in brown intensity when submitted to phenol. This fact was not observed, as the correlation estimate found was positive, but of low magnitude $\left(r=0.27^{*}, P<0.05\right)$ for the $L$ of the seeds before and after phenol $(L x L$ after phenol). The correlation estimates between the color parameters in the seeds after phenol reaction were positive and significant from each other $\left(a^{*} \times b^{*}=0.95^{* * *} ; L x a^{*}=0.69^{* * *} ; L \times b^{*}=0.95^{* * *}\right)$.

Table 1. Mean, minimum, maximum, variance, and standard deviation (SD) for color scores and color parameters (L, $a^{*}$ and $b^{*}$ ) evaluated in seeds of 88 triticale genotypes before and after phenol reaction.

\begin{tabular}{cccccc}
\hline Characteristic & Mean & Minimum & Maximum & Variance & SD \\
\hline Score $^{/ f}$ & 5.82 & 1.00 & 9.00 & 3.37 & 1.8354 \\
$\mathrm{~L}$ & 42.78 & 40.42 & 45.48 & 0.81 & 0.9027 \\
$\mathrm{a}^{*}$ & 6.35 & 5.52 & 7.49 & 0.12 & 0.3501 \\
$\mathrm{~b}^{*}$ & 16.07 & 14.17 & 18.36 & 0.53 & 0.7250 \\
$\mathrm{~L}^{/ f}$ & 30.86 & 24.87 & 46.29 & 11.44 & 3.3818 \\
$\mathrm{a}^{* / f}$ & 5.87 & 4.30 & 7.56 & 0.45 & 0.6704 \\
$\mathrm{~b}^{* / f}$ & 7.71 & 3.41 & 16.39 & 5.77 & 2.4018 \\
\hline
\end{tabular}

${ }^{\text {If }}$ Ccores and color parameters $\left(L, a^{*}\right.$, and $b^{*}$ ) evaluated after seed treatment with phenol solution.

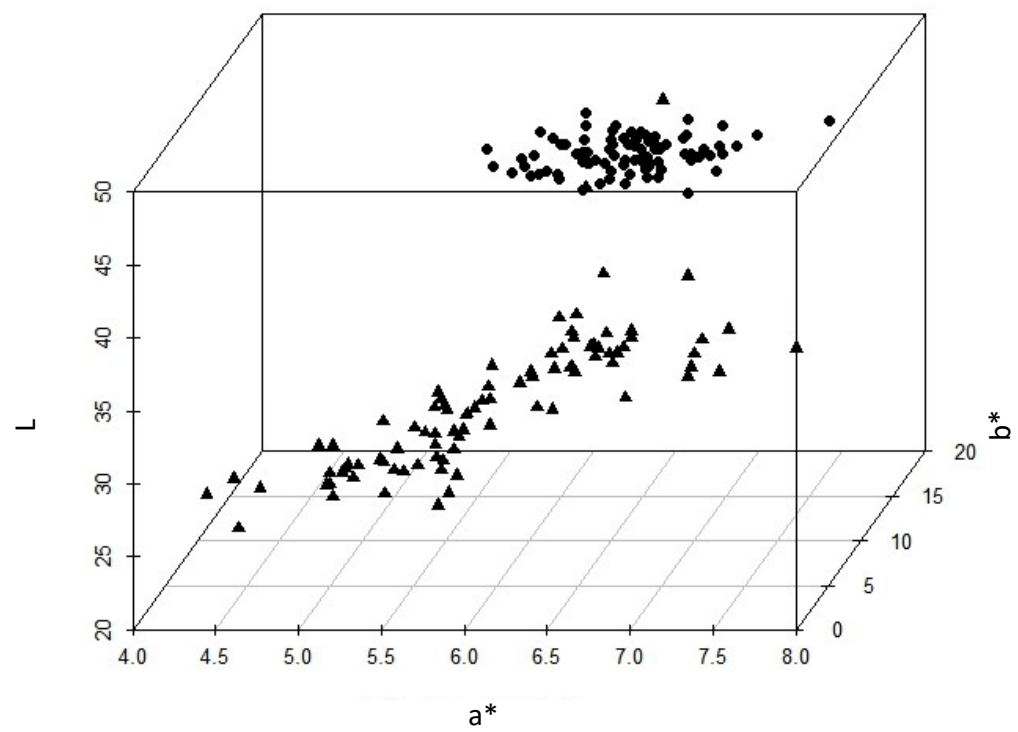

Figure 2. Values of the color parameters L (lightness), a* (green-red), and b* (blue-yellow) evaluated in seeds of 88 triticale genotypes after reaction with phenol solution $(\mathbf{A})$ and raw seeds $(\bullet)$. 


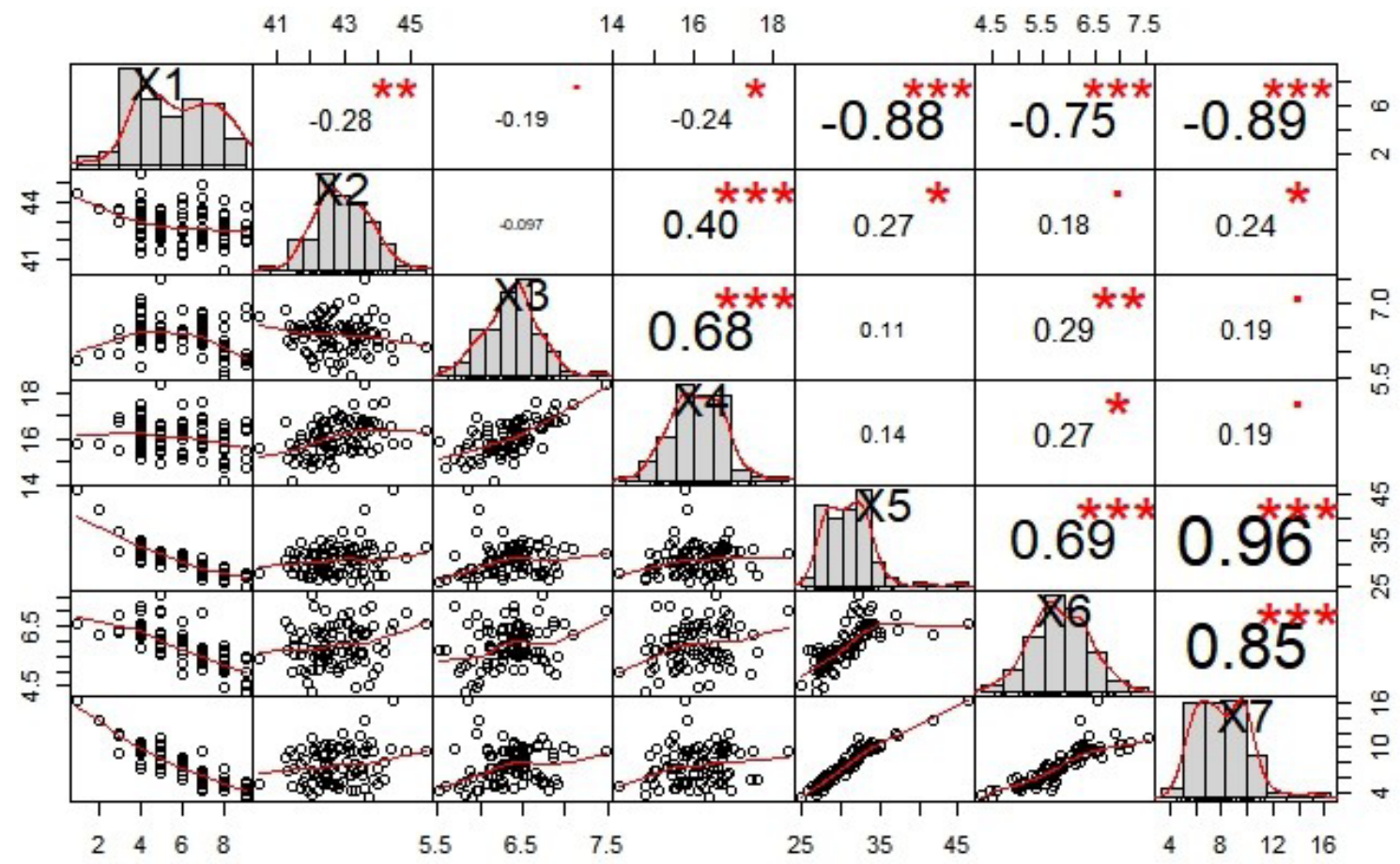

Figure 3. Estimates of Pearson's correlation coefficients in triticale seeds. Evaluated characteristics: X1) scores through visual evaluation; X2) L (lightness); X3) chromaticity $a^{*}$; X4) chromaticity $b^{*}$; X5) L (lightness); X6) chromaticity $a^{*} ; \mathrm{X7}$ ) chromaticity $\mathrm{b}^{*}$. The characteristics $\mathrm{X} 1, \mathrm{X} 5, \mathrm{X6}$, and $\mathrm{X7}$ were evaluated after the seeds were treated with phenol solution.

Table 2. Color parameters $\mathrm{L}, \mathrm{a}^{*}$, and $\mathrm{b}^{*}$ after reaction with phenol solution in triticale seeds evaluated for each color score in 88 triticale genotypes.

\begin{tabular}{cccccc}
\hline \multirow{2}{*}{ Visual evaluation } & $\begin{array}{c}\text { Phenotypic description } \\
\text { after phenol reaction }\end{array}$ & $\begin{array}{c}\mathrm{N}^{\circ} \text { triticale } \\
\text { genotypes }\end{array}$ & \multicolumn{3}{c}{ Color parameters } \\
\cline { 4 - 6 } & adsent / very clear brown & 1 & $46.3 \mathrm{ac}$ & $6.6 \mathrm{a}$ & $16.4 \mathrm{a}$ \\
2 & - & 1 & $41.9 \mathrm{~b}$ & $6.2 \mathrm{abc}$ & $13.8 \mathrm{~b}$ \\
3 & light brown & 3 & $35.5 \mathrm{c}$ & $6.5 \mathrm{ab}$ & $10.9 \mathrm{c}$ \\
4 & - & 22 & $33.3 \mathrm{~d}$ & $6.5 \mathrm{ab}$ & $9.7 \mathrm{~cd}$ \\
5 & brown (medium tone) & 15 & $31.6 \mathrm{de}$ & $6.1 \mathrm{abc}$ & $8.5 \mathrm{de}$ \\
6 & - & 11 & $30.7 \mathrm{e}$ & $5.8 \mathrm{bcd}$ & $7.5 \mathrm{ef}$ \\
7 & dark brown & 15 & $28.4 \mathrm{f}$ & $5.6 \mathrm{cde}$ & $6 \mathrm{fg}$ \\
8 & - & 14 & $27.8 \mathrm{f}$ & $5.3 \mathrm{de}$ & $5.4 \mathrm{~g}$ \\
9 & very dark brown & 6 & $26.9 \mathrm{f}$ & $4.9 \mathrm{e}$ & $4.5 \mathrm{~g}$ \\
\hline
\end{tabular}

Means within columns followed by different letters are significantly different according to the LSD test $(p<0.05)$.

Table 2 shows the mean values of the colorimetric parameters per score. The $L$, $a^{*}$, and $b^{*}$ values increase as the scores increase, indicating an increase in the contribution of the primary colors black, red, and yellow. The presence of representatives for all scores was verified in the evaluated genotypes. Score 4, which corresponds to the light brown/ 
medium color, was the most frequent class, with 22 individuals. Classes located at the extremes had the lowest number of individuals, in which scores 1 (absent/very light color) and 9 (very dark) included only one and six individuals, respectively (Table 2 ).

The visual evaluation allowed the easy detection of extreme scores, such as score 1 (very light color), score 9 (very dark brown color), and the midpoint, which corresponds to score 5 . However, the assignment of intermediate scores to these values is complicated because training is necessary to understand the differences in the gradation of more subtle colors on the seed outer surface. The visual evaluation of color using a score scale requires attention from the evaluator due to its difficulty. The assignment of scores for the intensity of brown color presented by the seeds after phenol reaction depends on the perception of the individual. Therefore, describing color using quantitative parameters avoids this type of adversity and ensures a more accurate characterization, and facilitates its comparison with other genotypes mentioned in the literature. For this reason, we proposed to group the mean values of the color parameters $\left(\mathrm{L}, \mathrm{a}^{*}\right.$, and $\left.\mathrm{b}^{*}\right)$ obtained using the colorimeter according to the score obtained through the visual evaluation (Table 2).

The visual scores ranged from 1 to 9 , representing color tones from very light to very dark (Table 2). Among the 88 triticale genotypes, score 1 was observed only in one genotype, which presents as a phenotypic description the phenol reaction absent/very weak. This information could be used as a reference in case of doubts in a later evaluation in the description of seeds classified as very lighter color by the visual evaluation and jointly by the parameters obtained using the colorimeter, in which the values $46.3,6.6$, and 16.4 could be used for $L$, a*, and b*, respectively. Genotypes whose seeds were classified as dark to very dark are found at the other extreme, corresponding to scores higher than 7 . Scores 7,8 , and 9 did not differ statistically from each other for L (LSD test at 5\%). Seeds classified as dark presented values equal to or lower than $\mathbf{2 8 . 4}$ for L, 5.6 for chromaticity $\mathrm{a}^{*}$, and 6.0 for chromaticity b*. Twenty-two triticale genotypes were assigned with an intermediate score (score 4), which corresponds to the phenotypic description from light to medium, with mean values of $33.3,6.5$, and 9.7 for $L$, $a^{*}$, and $b^{*}$, respectively. The other genotypes were found in the other groups shown in Table 2.

The use of instrumental techniques for quantifying color in products has been used for several decades, and the use of color space for this characterization seems appropriate for germplasm phenotyping (Jackson et al., 2018; 2019). The CIE LAB color space and other color spaces have been used successfully to quantify color parameters in various plant species, such as sweet potato (Jackson et al., 2018; 2019), bean (Kläsener et al., 2020), fruits (Gentallan et al., 2019), forest species (Bonfatti-Júnior and Lengowski, 2018), and medicinal plants (Gasparin et al., 2014). An objective color classification scale for triticale grains can be applied in the breeding program routine, especially in the characterization of germplasm or evaluation of a complementary characteristic of competition tests. It is expected that the quantification of colors could facilitate the comparison of information between databases of different studies in the literature.

\section{CONCLUSIONS}

There is variability for color expression after the seeds were submitted to phenol solution, as observed in the visual evaluation and quantified by the color parameters $L, a^{*}$, and $b^{*}$. The use of colorimetric parameters $\left(L, a^{*}\right.$, and $\left.b^{*}\right)$ had a practical and simple application in the color classification of triticale seeds after phenol reaction and allowed the formation of a database, facilitating the comparison of data from other studies in the literature.

\section{REFERENCES}

BONFATTI-JÚNIOR, E.A; LENGOWSKI, E.C. Colorimetria aplicada à ciência e tecnologia da madeira. Pesquisa Florestal Brasileira, v.38, p.1-13, 2018. https://pfb.cnpf.embrapa.br/pfb/index.php/pfb/article/view/1394/812

BRASIL. Ministério da Agricultura, Pecuária e Abastecimento - MAPA. Agrícolas: Triticale (x Triticosecale Witt). Brasília, DF, 2002. Available on: https://www.gov.br/agricultura/pt-br/assuntos/insumos-agropecuarios/insumos-agricolas/protecao-de-cultivar/ agricolas. Accessed on: 04 fev. 2020. 
COMMISSION INTERNATIONALE DE L'ECLAIRAGE. Colorimetry. 3rd. ed. Viena: Central Bureau of the CIE, 2004.82 p.

FERREIRA, D.F. Sisvar: a guide for its bootstrap procedures in multiple comparisons. Ciência e Agrotecnologia, v.38, n.2, p.109-112, 2014. http://www.scielo.br/scielo.php?script=sci_arttext\&pid=S1413-70542014000200001

GASPARIN, P.P.; ALVES, N.C.C.; CHRIST, D.; COELHO, S.R.M. Qualidade de folhas e rendimento de óleo essencial em hortelã pimenta (Mentha x Piperita L.) submetida ao processo de secagem em secador de leito fixo. Revista Brasileira de Plantas Medicinais, v.16, n.2, p.337-344, 2014. http://www.scielo.br/scielo.php?script=sci_arttext\&pid=S1516-05722014000500005

GENTALLAN, R.; ALTOVEROS, N.; BORROMEO, T.; ENDONELA, L.; HAY, F., LALUSIN, A.; YOSHIOKA, Y. Systematic establishment of colour descriptor states through image-based phenotyping. Plant Genetic Resources: characterization and utilization, v.17, n.1, p.91-94, 2019. https://www.cambridge.org/core/journals/plant-genetic-resources/article/systematic-establishment-of-colour-descriptor-statesthrough-imagebased-phenotyping/1ABDBD71F19FA09C76CF7E0677 2865ED

JACKSON, D.M.; HARRISSON, H.F.; JARRET, R.L.; WADL, P.A. Color analysis of storage roots from the USDA, ARS sweetpotato (Ipomoea batatas) germplasm collection. Genetic Resources and Crop Evolution, v.65, p.1217-1236, 2018. https://link.springer. com/article/10.1007/s10722-018-0609-6

JACKSON, D.M.; HARRISSON, H.F.; JARRET, R.L.; WADL, P.A. Phenotypic analysis of leaf colour from the USDA, ARS sweetpotato (Ipomoea batatas) germplasm collection. Plant Genetic Resources - characterization and utilization, v.17, n.4, p.1-14, 2019. https://www.cambridge.org/core/journals/plant-genetic-resources/article/phenotypic-analysis-of-leaf-colours-from-the-usdaars-sweetpotato-ipomoea-batatas-germplasm-collection/A932DE43 0D27B99F6D4BE96C81FF3C26

KLÄSENER, G.R.; RIBEIRO, N.D.; CASAGRANDE, C.R.; ARNS, F.D. Consumer preference and the technological and nutritional quality of different bean colours. Acta Scientiarum. Agronomy, v.42, e43689, 2020. http://www.scielo.br/scielo.php?pid=S1807$86212020000105006 \&$ script=sci_arttext

MENEZES, N.L.; BELLE, R.A. Identificação de cultivares de trigo pelo teste de fenol. Ciência Rural, v.25, n.2, p.315-316, 1995. http:// www.scielo.br/scielo.php?pid=S0103-84781995000200025\&script=sci_abstract\&tlng=pt

MOYA, M.E.; REINOSO, P.D.; GALUSSI, A.; SOLDA, G. Respuesta al fenol de los cariopsis de cultivares de cebada y centeno. Ciencia, docencia y tecnología, v.17, n.32, p.243-251, 2006. https://www.redalyc.org/articulo.oa?id=14503209

SINGH, C.; SRIPATHY, K.V.; PAL, G.; RAMESH, K.V.; SOMASUNDARAM, G. Delineation of inheritance pattern of aleurone layer colour through chemical tests in rice. Rice, v.10, n.1, p.1-10, 2017. https://thericejournal.springeropen.com/articles/10.1186/s12284-0170187-9\#article-info use, distribution, and reproduction in any medium, provided the original work is properly cited. 